\title{
LEXICON ACQUISITION IN AN INTERDISCIPLINARY LEARNING CONTEXT
}

\author{
Maria Paula Santos Soares da Silva Lago \\ paulalago@sapo.pt \\ Universidade do Minho, Portugal
}

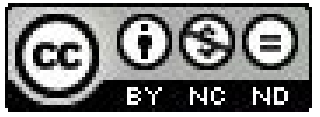

\begin{abstract}
This paper presents the questions that led to the field research, the theoretical frame, the subsequent methodology, and some of the results and conclusions. One of these conclusions is the need of specific tasks aimed at lexicon acquisition and of interdisciplinary work within that acquisition. Some strategies of minimizing failure and e learning enhancement will also be discussed, as well as the learning results achieved in the strict area of lexicon acquisition.
\end{abstract}

Key words: lexicon, active vocabulary, passive vocabulary, success, failure, strategies

\section{INTRODUCTION}

The project arose from empiric observation, at high secondary level, of learning troubles in diverse curricular subjects, which appear to be connected with student literacy level. Those troubles are generally verbalised by the students as "trouble in understanding subjects"; within evaluation tasks, this verbalisation includes a judgement about subject comprehension ("I do / I do not understand the subject") and / or verbalisation of trouble with the task itself ("I did not understand the question" / "I did not know what I was supposed to answer"). Teachers from other subjects often comment that "the major problem is that students are not proficient in their mother tongue", and they relate student's failure in evaluation tasks to this problem. They also often refer to the problem by an idiom that suggests cognitive biases in evaluation tasks: "perguntamos alhos e eles respondem bugalhos" ("the question is about apples and they answer about oranges").

The experience of teaching Portuguese at high secondary level (14-15 to 16-17 years old students) showed that student's failure was often related to trouble with understanding questions and/or concepts implied in subjects' comprehension, and trouble in structuring concepts, terms and data in a coherent discourse. Two significant features of errors in expression tasks were identified: inappropriate lexical choices and severe troubles in logical and syntactic organisation of terms and concepts in simple and complex propositions, which included errors in the selection of phrase, clause, and sentence connectors. These troubles led to a low proficiency in expression, either verbal or written. The problem ranged from errors that did not affect communication, although comprehensibility was endangered, to the extent where oral or written production became incoherent, or, in the case of written production, almost incomprehensible. 
During the scholar year that preceded the project presentation, Portuguese teaching and learning was performed in the final year of secondary school. Empirical observation showed that students experienced particular trouble in assembling diversified information in order to produce written analyses of literary texts; it was also noticeable that the trouble experienced appeared to be closely related to conceptual definition and / or lexical selection. Furthermore, the trouble experienced by the students appeared to influence other curricular subjects, with the common feature that Portuguese language was the linguistic tool to perform evaluation tasks.

The scholar year preceding the elaboration of the project was thus also devoted to literature review, in order to define theoretical framing and methodology to observe, and to the questions raised by empirical observation within a group starting high secondary level.

The hypothesis formulated was that mental images corresponding to words or expressions were not defined enough, and this indefiniteness could be due to the existence of particular discourses and discursive practices within each subject or discipline.

Particular attention was assigned to syntactic structures, as literature review showed a narrow connection between semantics and syntax.

A second step (second scholar year) would follow to test the conclusions. We would measure active and passive vocabulary in written tasks of students exposed to particular strategies and tasks, and compare these data with a similar group of students that did not follow the same method. Data were to be collected within initial written tasks, and at first and last evaluation unit.

The second step of the project has not been initiated due to institutional constraints.

\section{THEORETICAL FRAMEWORK}

Literature review focused on a theoretical framework that could provide tools to analyse students' performance in evaluation tasks within the learning context, in order to explain and thus prevent failure. As the question appeared to be connected to student's literacy and its role in failure or success in a learning context, we have tried to focus theoretical contributions on the following: literacy framing - meaning definition and construction, correlative cognitive processes, discourse analysis and discursive background frames. In what concerns vocabulary, we have maintained a traditional division between passive and active vocabulary.

In what is related to linguistics, we have tried to follow a cognitive approach that could help to understand mental operations leading to success or causing trouble or failure. It became notorious that some contributions (Lakoff, 1987; Lakoff, \& Johnson, 1980; Kleiber, 1990; Teixeira, 2001) considered classification as the core of language activity; it was also noticeable in those contributions that meaning and understanding were closely connected to social guidelines as classification features and possible world configurations. Meaning and comprehension depended also on individual classification background and on correlative personal mental maps of possible worlds and contexts. 
Another valuable contribution was the discourse analysis in what concerns enunciator's subjectivity and the representation of that subjectivity in an utterance, along with the conscience of addressee's own point of view. Kerbrat-Orecchioni (1980)has made a significant contribution in this matter, mainly in what concerns the analysis of modalities and, within it, the appreciative modality features.

It was also noticeable that semantic sliding within contractual significations which means different meaning for the same word or expression - is currently expressed by terms and mental processes traditionally connected with literary studies, or by metaphorical structures that might, otherwise, be considered as parasitic speech. Damásio $(1995 ; 2000)$ describes the memory of individual sensory experience trough life time as an inner narrative that leads to self conscience, even when that narrative is non-conscious, non-verbal or impossible to verbalise. Within several subjects or areas connected with social sciences or psychology we have been aware of systematic crossing of terms and concepts between linguistics and literary studies; this is noticeable in what concerns the concept of reframing as the reconstruction of a narrative in order to change its focus and presuppositions which corresponds to changing the global meaning of the original one by changing the relevance and function of one or more of its elements.

Eco $(1988$, p. 74) states that the meaning of speech depends not only on its terms or expressions, but it also lies on its context and background assumptions. He proposes the definition of scripts and frames, which he considers "des schémas d'action et de comportement" (Eco, 1988, p. 76), as a wide conceptual key to the comprehension of a discourse. Encyclopaedia-like semantics should, according to Eco (1992, p.311), consider instructions on contextual or circumstantial selection, outlining the way in which a term should or might be used under some contexts or circumstances of enunciation. Describing presuppositions under this outline (Eco, 1992, pp. 314- 344), Eco defines lexical presuppositions that depend on the semantic system, and existential presuppositions that depend on the communicative process and on the utterance of a particular enunciation (Eco, 1992, p. 317).

Eco stresses the difference between background and foreground information and highlights the distinction between presuppositional and positional power. Presuppositional power arises from a linguistic device that shapes a contextual pattern for foreground information, and this foreground information must be accepted as incontestable by the speaker and the addressee. Since a presupposition depends on a communicative strategy whose background patterns may only be defined within enunciation itself, positional power is the power of imposing a given presupposition; unless the addressee challenges the background information, and the possible world implied in it, the term or expression acquires a positional power and establishes a point of view for the foreground information, framing the speech from then on (Eco, 1992, pp. 319-320).

Eco states later (1999, pp. 278-328) that frames and scripts include semantic-pragmatic and dialogical specifications within established social conventions, and emphasizes again the fact that linguistic structures do not refer to concrete entities unless they are embedded in speech (Eco, 1999, p. 279). Eco maintains (Eco, 1999, p. 328) that the same linguistic structure may mobilise different and 
mutually exclusive scripts, according to diverse contextual background assumptions. Those assumptions and the background do not depend on the grammatical structure, but on the speaker's intention and on the addressee's presuppositions.

Within this perspective, lexicon acquisition in a learning context appears as a particular kind of contract between meaning and discourse; terms and concepts should be learned and verbalised, understood and properly applied, and it should be so in all subjects and disciplines. This raises questions about literacy, dialogy, and discursive practices implied in the learning process.

In what concerns school discursive practices and addressee's frames and scripts, we have acknowledged, along with Van Dijk (1981, p. 65), the intersubjectivity of mental constructions in the addressee's configuration of text and context, highlighting a two-way influence through individual cognitive disposition: "il est évident que l'influence du texte sur la situation sociale de même que l'influence de la situacion sociale sur le texte s'exèrcent par le biais de de la disposition cognitive de l'usager" (Van Dijk, 1981, p. 88). Van Dijk also underlines that stylistic and rhetorical strategies are closely connected to the addressee's intention, as well as with his configuration (Van Dijk, 1981, p. 88).

School discursive practices might then be determined by discursive tradition, according to Jameson (1991, p. 9): "texts come before us as the always-already-read; we apprehend them trough sedimented layers of previous interpretations, or - if the text is brand-new - trough the sedimented reading habits and categories developed by those inherited traditions that shape interpretation". Categorisation and reading habits will result in the addressee's cognitive dispositions related to school discursive practices, within reception as well as production.

The semantic, pragmatic and dialogical specifications involved in the school discursive practices are then to be considered within traditions, habits and aims of literacy construction, according to discursive learning patterns and habits within school tasks and learning results, since the frames and scripts involved in discourse comprehension and production are determined by such social practices. In his work on literacy, James-Paul Gee (1989, p. 21) supports this perspective, as he believes that "viewpoints are always imbedded in a discourse". He also defines discourse as "a socially accepted association among ways of using language, of thinking, and of acting that can be used to identify oneself as a member of a socially meaningful group or "social network»" (Gee, 1989, p. 18), and considers that "literacy is control of secondary uses of language (i. e. uses of language in secondary discourses" (Gee, 1989 , p. 23). This is a decisive feature of native language learning in school, since native language encloses almost all school discursive practices. As the core of Portuguese language teaching and learning, there is in fact a transversal communication competence that includes linguistic, discursive/textual, sociolinguistic and strategic competences, which would lead to a powerful literacy. According to Gee (1989, p. 23), "powerful literacy is control of a secondary use of language used in secondary discourse that can serve as meta-discourse to critique the primary discourse or other secondary discourses, including dominant discourses". However, as the same author maintains (Gee, 1989, p. 23-24):“[...] mainstream middle-class children often look as they are learning literacy (of various sorts) in school. But in fact I believe much rese- 
arch shows they are acquiring these literacies through experiences in the home both before and during school, as well by the opportunities school gives them to practice what they are acquiring [...]. The learning they are doing, provided it is tied to good teaching, is giving them not literacies, but meta-level cognitive and linguistic skills that they can use to critique various discourses throughout their lives".

In fact, this powerful literacy would be the desirable output of learning and teaching within native language, at least as it is designed in curricular prescriptions. It should be so within transversal verbal and non verbal competences that would allow the student to develop a critical perception of reality, of discourses, and of himself/herself as a discourse producer and an addressee.

\section{WORK GROUP}

The project included a group of 52 students in two classes of $10^{\text {th }}$ year $(14-15$ years old). We did not establish a gender distinction. The first assessment from teacher's class council pointed to rather heterogeneous groups in what concerned their social and cultural stratum and learning profile. Both classes performed the same tasks and activities and results were analysed as a whole. We have requested the participation of teachers from other disciplines in the project, but only episodic collaboration has been achieved.

\section{METHODOLOGY}

Students took the same global diagnostic test that was administered to all students of the $10^{\text {th }}$ year. The test was chosen by a group of all Portuguese Language teachers of the above-mentioned year, and followed closely the manual proposal for initial diagnosis. Exception was made for oral comprehension task, where we have elaborated an oral comprehension task to check some of the initial hypothesis about textual competence, and for a written comprehension task designed with the same objectives.

The results were analysed within theoretical framing initially designed and according to the hypothesis stated. Since the collaboration of teachers from other disciplines has been episodic and did not allow systematic analysis, we have later designed particular interdisciplinary questions to check the hypothesis assigned.

\section{QUESTIONS AND RESULTS SELECTED FOR THIS PRESENTATION}

We will present the results of the analysis of the first written comprehension / expression task.

\section{DATA ANALYSIS AND CONCLUSIONS: SYNTHESIS TASK}

The standardised diagnostic test included an initial synthesis question about author's ideas along the first paragraph of a given text (see Annex 1 for the original text and free translation of our responsibility).

The question was "Synthesise the author's ideas in the first paragraph of the 
text presented". The first problem noticed was related to modality, as 7 of the 52 students showed explicitly their perception of deontic modality (that may be related to the use of majestic plural, even if the speech is clearly within the appreciative modality). This changing shows a generalisation that is a source of topic and semantic sliding from the original enunciation, which furthermore has been confirmed by the utilisation of the very same plural in text production. This plural integrates the students' discourse and it might be connected to a world configuration with stereotypic deontic discourses about books and reading. The examples of this perception are statements as <the author says >:"books are important in our lives" or "books are essential in all houses".

This suggested a particular care in what concerns the work on the distinction between reported speech and student's own discourse.

The second group of problems is a semantic slide through negation of a main proposition and correlated inferences. 8 students showed such a kind of interpretation practice, all within the same meaning focus ("the author likes"), showing, however, the possibility of semantic and pragmatic slide between the original and the related discourse. We believe this practice may be connected with the imperative of paraphrasing in a task of this kind, and that it points to the incapacity of lexical selection alternatives. The examples are the following:

$<$ o autor $><$ diz que $>$

1. não se sente confortável numa casa sem livros

2. não gosta de estar sem a presença de livros

3. não gosta de uma casa sem a presença constante dos livros

4. não imagina a vida sem a presença de livros

5. também diz que já não sabia viver sem a presença <dos livros>

6. praticamente não vive sem eles

7. estranha a sua ausência <dos livros> nas casas

8. uma casa sem livros não tem hospitalidade, portanto ele não se sente confortável sem a presença de livros

$<$ the author $><$ says that $>$

1. he does not feel comfortable without the presence of books

2. he does not like to be without the presence of books

3. he dislikes a house without the presence of books

4. he cannot imagine his life without the presence of books

5. he also says that he would not know how to live without the presence of books

6. virtually cannot live without them

7. he is puzzled by their absence <of the books > in the houses

8. a house without books is not hospitable, so he does not feel comfortable without the presence of books

The results suggest that students had serious trouble in lexicon selection within a paraphrase task and, furthermore, that they had no conscience of the different semantic and pragmatic extension of terms, concepts and world configurations between the original speech and the reported speech they were producing. This suggested a particu- 
lar care in the analysis of world configurations implied in a discourse, and within it, with semantic extension of words or concepts, mainly when affected by negation.

The third kind of problems detected in this task can be characterised, at first sight, as a complete divergence from what the paragraph of the text expresses. Although some of the interpretations might be considered as implicit or presuppositions, those implicit interpretations or presuppositions cannot be directly related to the first paragraph. 19 students produced statements that we believe to be related to the interference of personal or common sense judgments about the world configuration shaped by the text, and many of those assertions point, furthermore, to a confluence of textual meanings from other preceptive discourses and discursive practices, such as social or scholar ones. Students' texts specimens are presented bellow, followed by a literal translation that we believe may also show the problem:

$<$ o autor $>$ / <diz>

1. não há uma casa que não esteja repleta de livros

2. <refere> as lembranças dos livros enquanto ocupam, por completo, as casas onde se situam

3. que se deve ler, ler muito e que muitas vezes os livros ajudam nos afectos

4. gosta de ter livros em casa, bem arrumados, limpos porque eles podem durar muito tempo

5. dá a entender que para ele a alegria vem dos livros

6. < < livros> são uma fonte de sabedoria

*é necessária a presença dos livros em todas as casas, que estes são insubstituíveis e importantes

7. admira quem possui livros

8. informações tanto desconhecidas como valiosas < nos livros>

9. os livros devem estar em todo o lado possível

10. os livros são divertidos

11. <os livros> são realmente fundamentais para a vida passada

12. é com eles que aprendemos desde a primeira letra do alfabeto até à enciclopédia

13. os livros são importantes em casa porque mostram que os habitantes têm conhecimentos e pretendem adquirir mais conhecimentos

14. são muito importantes porque nos ajudam a crescer como pessoas

15. dão interesse a uma casa

16. não só porque <os livros> nos torna em pessoas mais cultas

17. acha que se deve ter a casa com livros porque dá outro ar

18. também demonstra que os livros, ao contrário, por exemplo, de um filme, não está apenas a transmitir um lado ou perspectiva de uma história, dão a liberdade de imaginar e recriar o seu próprio cenário ao autor

19. os livros são imortais, que embora tenham mais de 200 ou 300 anos continuam vivos

<the author > / <says>

1. there exists no house that is not full of books

2. <refers to> memories of books as they occupy, completely, the houses where they are situated

3. that one should read, read a lot, and that often books help with affection 
4. he likes to have books at home, tidy, clean, because they can last for a long time

5. suggests that, to him, joy comes from books

6. <books> are a source of wisdom

* that the presence of books is a necessity in all houses, that they are irreplaceable and important

7. admires those who own books

8. information unknown, as well as valuable <in the books>

9. books should be in all possible places

10. books are fun

11. <books> are really fundamental for past life

12. it is from them that we learn from the first character of the alphabet to the encyclopaedia

13. books are important at home because they show that the inhabitants have knowledge and intend to acquire further knowledge

14. they are very important because they help us to grow as a person

15. they make a house 16 . not only because <books> make us more cultivated persons

16. thinks that one should have a house with books because they provide a different ambiance

17. also demonstrates that books as opposed to films, not only show one side or a perspective of a story, they provide the liberty of imagining and recreating his own scenery to the author

18. books are immortal, though they are more than 200 or 300 year they are still alive

We have collected examples of mistakes which appear as not directly connected to lexicon and inappropriate lexical selection; however, most of them are connected with stereotypic mental images that affect the discourse by contamination with topics associated to that mental image, whether those topic are, or not, present in the discourse analysed. The same problems can be detected in further examples of inappropriate lexical choices (that must be added to the precedent). In all the examples presented below there are inappropriate logical-syntactical choices that point to semantic or phonetic analogy with a portion of the mental image that the students recall within the particular discursive situation, as follows;

1. o autor resume-se a deixar-se levar pelos sentimentos

This example points to the mixing between limita-se ("limits himself < to follow his feelings $>$ ") and resume-se ("<the position of the author $>$ may be summarized <as being carried by his feelings>"

2. os livros são os meios onde aprendemos constantemente

This example points to the interference of meios/instrumentos with lugares/ meios ("books are means for apprenticeship", "books are tools for learning", and "books are ambiances where we learn".

3. o autor tenta comunicar que os livros [...] tentam-nos fazer recordar momentos vividos na infância

This exemple points to interference between dizer and comunicar; it is mainly a syntactic interference, since proper choices would be "comunicar a ideia de que os livros [...] or "dizer que os livros [...]". 
4. as ideias representadas no primeiro parágrafo

This example points to phonic and semantic interference between apresentar ("present") and representar ("represent").

5. as ideias que o autor nos faz transparecer

This example points to syntactic interference of dar a entender and dar-nos a entender, with the semantic extension of the expression deixar transparecer. Difficult to translate to English, the main question is that the last one does not allow indirect complement, and that both expressions carry the meaning of indirect speech acts or positional power of a statement. This answer also does not respect the explicit meanings of the text, and also appears to be caused by the imperative of the paraphrase. 6. o autor transpõe a importância dos livros e o seu prazer de ler This example points to the interference of transpor ("transfer") and transmitir ("transmit") as synonyms, or a lack of conscience of a frequent formula in school discourse that would need a predicate complement ("the author transfers to the text the importance of books and his pleasure in reading").

7. os livros transmitem prazer quando os relê-mos

This example points to indistinction of pragmatic situations and semantic extension of dar (give) and transmitir ("transmit").

The examples described above as well as the results of the analysis of other written or oral expression tasks showed the necessity of strategies leading to an awareness of the dimensions implied in lexicon selection. It also became clear that formal lexicon learning was needed, and that this learning could not be restrained to synonymies exercises or to the use of a dictionary.

\section{STRATEGIES AND RESULTS}

\section{Strategies}

The work of written comprehension was focused on analysis and synthesis; the work of written composition was mainly that of short or medium composition, with special focus on lexicon selection and syntax.

The group has performed an exploration of Latin and Greek roots, stems and prefixes. We accorded with the students that even in formal testing situations they would use conventional signs before lexical choices or syntactic connectors whenever they were conscious of doubt in their use. We believe this strategy promotes critical reflection on lexicon and active vocabulary development. Knowing that they would not be penalised in the case of inappropriate choice, student are confident to essay new words in context, and that also provides the teacher with the opportunity to suggest adequate substitution or further development.

We have also developed formal lexicon learning, explicitly in five dimensions: 1. Discursive contexts (including knowledge or activity areas, communicative situations, language register) 2. semantic intension and extension, basic semantic features, including axiological dimension when required; 3. Metaphorical dimension, whenever needed, according to metaphorical use; 4 . valency / syntactic context; 4 . etymology and history of use (when it is required by the specificity of a word or expression).

The formal examples for this task were the learning of the adjective contíguo 
("contiguous"), which students defined: 1. In mathematics, formal communication situations, formal style or scientific jargon; 2. implies two elements, one starting were the other finishes, (we cannot say that two oceans are contiguous), implies a spatial dimension; 3 . not very usual as a metaphor; 4 . A (is) contiguous to $\mathrm{B} / \mathrm{A}$ and $\mathrm{B}$ are contiguous.

\section{Results}

Te group showed a progressive development of vocabulary along the scholar year. The initial diagnostic extensive written production (150-200 words) was repeated at the end of the year: 14 of the 51 students (one left the group during the year) presented inappropriate lexical choices, with 18 total occurrences. The initial results had been 23 students and 28 occurrences.

\section{REFERENCES}

Eco, U. (1988). Sémiotique et Philosophie du Langage [Semiotics and the Philosophy of Language]. Paris: PUF. Eco, U. (1992). Os Limites da Interpretação [The Limits of Interpretation]. Lisboa: Difel.

Eco, U. (1999). Kant e o Ornitorrinco [Kant and the Platypus]. Lisboa: Difel.

Damásio, A. R. (2000). O Erro de Descartes [Descartes' Error]. Lisboa: Publicações Europa-América.

Damásio, A. R. (2001). O Sentimento de Si. O Corpo, a Emoção e a Neurobiologia da Consciência [The Feeling of What Happens: Body and Emotion in the Making of Consciousnes]. Lisboa: Publicações Europa-América.

Gee, J. P. (1989). Literacy, discourse and linguistics. Journal of Education, Vol.171, n. 1, 5-25.

Jameson, F. (1991). The Political Unconscious. Narrative as a Socially Symbolic Act. Ithaca, New York: Cornell University Press.

Kerbrat-Orecchioni, C. (1980). L'Énonciation de la Subjectivité dans le Langage [Enunciation of Subjectivity in Language]. Paris: Armand Colin.

Kleiber, G. (1990). La Sémantique du Prototype [Prototype Semantics] . Paris: PUF.

Lakkof, G. (1987). Women, Fire and Dangerous Things: What Categories Reveal about the Mind. Chicago and London: University of Chicago Press.

Lakoff, G., \& Johnson, M. (1980). Metaphors We Live By. Chicago: University of Chicago Press.

Teixeira, J. (1996). Branco é, galinha o põe (Entradas lexicais e Significado de Comunidade) [It is white, a chicken lays it (Lexical entries and Community Meaning)] . Encontro Nacional da Associação Portuguesa de Linguística : actas. vol. 2, pp. 229-236. Retrieved from http://hdl.handle.net/1822/4278

Teixeira, J. (2002). Quando "nos alagamos no Inferno"... (História, na língua, de uma mudança semântica). [When we "we are flooded <pulled down> in hell" (The history of a semantical change in the language)]. In: B.F. Head, et al. (eds.). História da língua e história da gramática: actas do Encontro de História da Língua e História da Gramática, Braga, 2000. Braga: Centro de Estudos Humanísticos da Universidade do Minho. (pp. 449-457). Retrived from http:/ / hdl.handle.net/1822/3614

Teixeira, J. (2004). Frente/trás (front/back) : space and its verbalization: the Portuguese case. In: A. S. da Silva et al. (eds.). Linguagem, cultura e cognição : estudos de linguística cognitiva vol. 2 (pp. 93-117). Lisboa : Almedina. Retrieved from http://hdl.handle.net/1822/5310

Teixeira, J. (2005). Organização conceptual das categorias e a lexicalização de um protótipo (fruta). [Conceptual Organization of Categories and the Lexicalization of a Prototype (fruit(s)]. DiacríticaSérie Ciências da Linguagem, 19/1, 239-280. Retrieved from http:/ / hdl.handle.net/1822/4509

Teixeira, J. (2007). Mecanismos Metafóricos e Mecanismos Cognitivos: Provérbios e Publicidade [Metaphorical Mechanisms and Cognitive Mechanisms: Sayings and Advertising.] In: Actas del VI Congreso de Lingüistica General, Madrid: Arco Libros. Retrieved from: http:/ / hdl.handle.net/1822/7400

Van Dijk, T. A. (1981). Le Texte: Structures et Fonctions. Introduction Élémentaire à la Science du Texte [Text: Structures and Functions. An Elementary Introduction to the Science of Text]. In: A. Kibédi Varga (ed.). Théorie de la Littérature. Paris: Picard. 


\section{ANNEXES}

\section{A presença dos livros}

Gosto das casas com livros e da alma que eles alimentam. E falar de livros é lembrar a sua presença a ocupar amigavelmente todos os cantos das casas onde eles existem. Não concebo a hospitalidade de uma casa sem a omnipresença dos livros. E não há prazer maior do que ir à estante e folhear um livro, que já não recordamos, do qual temos uma lembrança vaga ou que julgamos ter bem presente. No fundo, os livros fazem parte dos nossos afectos. No entanto, porque os livros vivem, ou não fossem a projecção permanente dos seus autores nas nossas vidas, é normal que quando os relemos, e julgamos conhecê-los, descubramos novas ideias, novas perspectivas, cambiantes diferentes como se fossem eternamente novos.

As bibliotecas são sempre lugares iniciáticos, misteriosos, labirintos autênticos e inesgotáveis. [...] As minhas primeiras recordações da biblioteca fantástica de meu Avô têm a ver com as Enciclopédias e os Dicionários. Foi por aí que comecei, na tentativa, sei hoje que vã, de procurar as saídas dos labirintos. E lembro-me bem dos sábados, passados até que a luz se desvanecesse, a correr de Herodes para Pilatos nas várias entradas do velho "Dicionário de Portugal", a descobrir os vultos do nosso oitocentismo, a desvendar uma gigantesca Enciclopédia espanhola ou o "Larousse Illustré", a folhear os Atlas e os livros imponentes e pesados com as reproduções já um pouco desmaiadas das grandes obras de arte do mundo, nos grandes Museus, desde o Louvre aos Ofícios de Florença, passando pelo misterioso Hermitage... Eram horas esquecidas, em companhia da multidão de mortos que povoavam essa encruzilhada única que era a livraria de meu Avô (biblioteca e livraria eram sinónimos no vocabulário lá de casa).

Penso que o vício dos livros veio no meu código genético. Nunca me senti bem sem eles. Equando há o vício de lidar com livros, tudo o que vem à rede é peixe. E, a pouco e pouco, depois da História, que havia para todos os gostos (o meu Avô era professor de História e Geografia), vinha o território da poesia e dos romances -- dos romances, inevitavelmente. Entre duas revoluções e quatro viagens virtuais ou imaginárias (Odisseia, Ilíada, Eneida, Gulliver, Robinson e Júlio Verne) ia à poesia (Camões, Garrett, Antero, Cesário, Pessanha) e aos romances, às colecções completas de Camilo e de Eça, sem restrições. Lá estavam todos [...] Aos desaparecidos das enciclopédias juntava-se a outra multidão das personagens romanescas: Simão Botelho e Teresa de Albuquerque, Zé Fernandes, Jacinto, Carlos, Maria Eduarda, Basílio, Luísa...

[...]

E fica uma enorme saudade dessas aventuras e de quando minha Mãe vinha dizer serenamente que era chegada a hora de voltar.

Guilherme d'Oliveira Martins, in Os Meus Livros, Número 63, ano 6, Maio 2008

\section{The presence of the books}

I like houses with books and how they feed the soul. Speaking about books is reminding of their presence, occupying in a friendly way all the places of the houses where they are present. I can't conceive the hospitality of a house without the omnipresence of books. And there is no greater pleasure than going to the bookshelf and browsing through a book that we don't remember anymore, from which we have a vague memory or that we are sure to remember well. After all, books are a part of our affections. However, because books live - as they are a permanent projection of their authors in our lives - it is not surprising that, whenever we read them again believing that we already know them, we still find out new perspectives, different nuances as if they were eternally new. Libraries are always initiatory, mysterious places, real and inexhaustible labyrinths [...] My first memories of my grandfather's fantastic library are related to Encyclopaedias and Dictionaries. It was there that I have started, trying, in vain as today I realise, to find my way out of the labyrinths. And I remember well the Saturdays I spent, until the light faded, running from Herod to Pilate in the various entries of the old "Dicionário de Portugal", discovering the prominent figures of our 19th century, unveiling an enormous Spanish Encyclopaedia or the "Larousse Illustré", browsing through the Atlas and through the imposing and heavy books with their faded illustrations of the world's major artworks, in the great museums, from the Louvre to Florence' Uffizzi, and to the mysterious Hermitage. Those were unnoticed hours in the company of a dead crowd that populated the unique crossroad that my grandfather's library happened to be (library and bookshop synonymous in the house's vocabulary).

I think that book addiction came in my genetic code. I never felt well without them. And in what concerns book addiction, all's fish that comes to the net. And, step by step, after History which would serve any taste (my grandfather was an History and Geography teacher), came the territory of poetry and novel - novel, inevitably. Between two revolutions and four virtual or fictional journeys (Odyssey, Iliad, Aeneid, Gulliver, Robinson and Jules Verne) I would go to poetry (Camões, Garrett, Antero, Cesário, Pessanha) and to novel, to the complete collections of Camilo and Eça, without any restriction. Joining the deceased from the encyclopaedias, entered the crowd of novelesque characters: Simão Botelho e Teresa de Albuquerque, Zé Fernandes, Jacinto, Carlos, Maria Eduarda, Basílio, Luísa...

[...]

And I really miss those adventures and the time when my mother would come and quietly say that it was time to go home. 